\title{
IMPROVING THE STUDENTS' READING COMPREHENSION THROUGH EXPLICIT TEACHING STRATEGY
}

\author{
Nur Qalby \\ English Education Department, Faculty of Teacher Training and Education \\ Muhammadiyah University of Makassar \\ nurqalbi@unismuh.ac.id.
}

\begin{abstract}
This research aimed at explaining the improvement of the students' reading comprehension focused on identifying main idea and getting detail at SMP Negeri 33 Makassar. To explain the improvement, the researcher used a classroom action research (CAR) which was conducted in two cycles in which every cycle consisted of four meetings. The location of this research was taken at the second grade student of SMP Negeri 33 Makassar with the number of the subject i.e. 30 students which consisted 14 men and 16 women. Based on the text above the research findings indicated that the use of Explicit Teaching Strategy was significant in improving the students' reading comprehension which focused on identifying main idea and getting detail. It was proved by the mean score of Diagnostic Test was 4.94 that classified poor. The improvement in Cycle I was 6.11 that classified fair and Cycle II was 7.26 that classified fairly good. While the standard target achievement was 6.5, it means that the standard target achievement had been achieved.
\end{abstract}

Keywords: reading comprehension, main idea, classroom action research

\section{INTRODUCTION}

In learning language English there are four skills that should be master in learning they are listening, speaking, reading, and writing. Those are very important for English learners. Reading skill is one of the main points to master English because a lot of students have opinion that reading an important target, with reading they can get information and entertainment beside for their career and study target. So that's why I will focus on reading comprehension skill in my research. As support for students in improving reading skill, student have to be give knowledge about component of language, such as knowledge about vocabulary, structure, pronunciation; sound for help their skill language.

The other it curriculum and system education also will assist teachers in improving education by significant especially learning English language. In improving reading comprehension skill of students', teachers have to use good strategy, precise method, and resource of study, media on learning 
assessment process and evaluation. To know about it, hence previously researcher have to do observation, and after researcher doing observation at SMP Negeri 33.

Makassar, hence obtained result on learning English Language that is student not focus when learning process. The student reading skills still poor. Only a few students can understand what they have read especially English text. Because many factors such as the students consider that English is a subject that very difficult, boring, and meaning and letters are different. As value of observation is the classroom the students got mean score 5.5 but the standard of curriculum 6.5 and the target score is 7.0 in learning reading comprehension.

By looking this fact, the researcher will give variation of teaching strategy. It is a good strategy to help students active their prior knowledge. That is explicit teaching or instruction is a generic plan for developing a wide range of strategies. It seems to be an appropriate framework for teaching students at all age by Leys (1984:73), and Kamil, Borman (2008:11) explicit teaching or instruction can also include specific teacher activities that have been demonstrated to improve students' comprehension of texts.

\section{CONCEPTS OF EXPLICIT TEACHING STRATEGY}

\section{Definition of Explicit Teaching or Instruction Strategy}

Explicit Instruction is a systematic instructional approach that includes set of delivery and design procedures derived from effective schools research merged with behavior analysis. There is two essentials component to welldesigned explicit instruction a. visible delivery features are group instruction with a high level of teacher and students interactive, b. the less observable instructional design principles and assumption that make up the content and strategies to be taught by (Tracey 2002:2).

Explicit is something that is clearly expressed or communicate. In the quest to maximize students' academic growth, one of the best tools available to educators is explicit instruction strategy. A structure, systematic and effective methodology for teaching academic skills is called explicit because it is an 
ambiguous and direct approach to teaching that includes both instructional design and delivery procedures. Explicit teaching or instruction is characterized by a series of support or scaffolds, where by students are guided through the learning the new skill, clear explanations of the instruction target, and supported practice with feedback until independent mastery has been achieved. Rosen shine in Anita (2011:11) describe this form of instruction as "a systematic method of teaching with emphasis on proceeding in small steps, checking for students understanding and achieving active and successful participation by all students".

While, Pearson and Leys (1984:73) said explicit teaching is generic plan for developing a wide range of strategy. It seems to be an appropriate framework for teaching students at all age. While Dr. N. Boyles (2004-2009:18) says that explicit teaching is more complex than we might wish it to be, which is why good written responses (and other quality students products) often elude us.

Than by Edward (1998-2002:1) says that Explicit Teaching is not just merely giving students and starting the learning goals at the beginning of a lesson- it is a way of thinking about and acting out teaching and learning in a principled way throughout the lesson (from assessment through to planning, implementation and review). Explicit instructional talk is evident when it directly and intentionally prepares students for their learning, informs them of the learning path and enables them to develop meth cognitive strategies for knowing that learning has taken place. And explicit teaching is essentially about the talk of classroom lessons. Careful examination of literacy interactive practices in the context of classroom teaching practice and leads to important conclusions about instructional for all students.

\section{The Implementations of Explicit Teaching in Teaching Reading}

According to Person and Leys (1984:73) there are six stages to implementation in the classroom. They are:

a. Introduction. Teacher introduces the skill or strategy through examples and review, teacher refers the students to examples of the "real word", including the purpose for using the strategy. 
b. Optional. The teacher chooses the student to volunteer additional examples and discuss them.

c. Label, model, and explain the skill or strategy. In this step, the strategy is a given through demonstration with teacher modeling.

d. Guided practice. In the step, teacher gives example are done together in order to prepare the students for independent practice.

e. Independent practice. In the step, the student work together through the same type of exercise.

f. Application. The students are given a variety of situation in which they are encourage to apply this skill or strategy to other text or situations outside school.

\section{METHODOLOGY}

This study was designed for a Classroom Action research (CAR) in which the researcher acts on the procedures of the study, namely: planning, action, observation, reflection. This research was divided in two cycles, they were first and second cycle. And each cycle was the series of activities which have close relation, were the realization of the second cycle was continued and repaired from the first cycle. There were two variables of this research. The use of Explicit Teaching Strategy was independent variable. Reading comprehension particularly in identifying main idea and content of the text was dependent variables. Research subject in this classroom action research were the second grade student of class eight at SMP Negeri 33 Makassar.

The class consisted of 30 students with 16 women and 14 men. In this research, the researcher used two instruments, those were observation and test. Observation aimed to find out the students' data about their activeness/participation in teaching learning process. The researcher gave written test about the students' reading comprehension through Explicit Teaching Strategy in the last meeting of every cycle to find out how is the improvement of the students' understanding in reading comprehension through Explicit Teaching Strategy. 


\section{FINDINGS}

\section{The Improvement of the Students' Reading Comprehension}

The improvement of the students' reading comprehension of second grade student of SMP Negeri 33 Makassar through Explicit Teaching Strategy can be seen clearly in the following table:

Table 1: The Improvement of the Students' Reading Comprehension

\begin{tabular}{|c|c|c|c|c|c|c|}
\hline \multirow{2}{*}{ No } & \multirow{2}{*}{ Indicator } & \multicolumn{3}{|c|}{ The Student's Mean Score } & \multicolumn{2}{|c|}{ Improvement (\%) } \\
\hline & & D-Test & Cycle I & Cycle II & DT to CI & CI to CII \\
\hline 1. & Main Idea & 4.86 & 6.13 & 7.2 & 26.13 & 17.45 \\
\hline \multirow[t]{3}{*}{2.} & Detail & 5 & 6.1 & 7.33 & 22 & 20.16 \\
\hline & 9.86 & & .53 & 48.13 & 37.61 & \\
\hline & $X$ & & & & 4.1 & .8 \\
\hline
\end{tabular}

The table above indicates that the improvement of the students' main idea and content in reading comprehension before application of Explicit Teaching Strategy indicates that the Diagnostic Test assessment (4.94) and after application in Cycle 1, the assessment of the student reading comprehension become higher (6.11) and the students' assessment in Cycle II (7.26). The assessment of Cycle II is better than Cycle I $(7.26>6.11)$ and classified as good which there is improvement from Diagnostic Test to Cycle I (24.1\%) and Cycle I to Cycle II $(18.8 \%)$ of the students reading comprehension.

\section{The Improvement of the Students' Main Idea and Detail}

a. Main Idea

The application of Explicit Teaching Strategy in improvement of the students' reading comprehension in terms of main idea can be see the 
difference by considering the result of the students' Diagnostic Test and the students' achievement after taking action in Cycle I and Cycle II through the application of Explicit Teaching Strategy in teaching and learning process.

Table 2: The Percentage of the Students' Main Idea Achievement

\begin{tabular}{|c|c|c|c|c|c|c|c|}
\hline \multirow{3}{*}{$\begin{array}{l}\text { No Classification } \\
\text { Range }\end{array}$} & & \multirow{2}{*}{\multicolumn{2}{|c|}{$\begin{array}{c}\text { Non ET } \\
\text { D-Test }\end{array}$}} & \multicolumn{4}{|c|}{ The Application of ET } \\
\hline & & & & \multicolumn{2}{|c|}{ Cycle I } & \multicolumn{2}{|c|}{ Cycle II } \\
\hline & & Freq & $\%$ & Freq & $\%$ & Freq & $\%$ \\
\hline 1. Excellent & $9.6-10$ & 0 & 0 & 0 & 0 & 2 & 6.66 \\
\hline 2. Very Good & $8.6-9.5$ & 0 & 0 & 0 & 0 & 0 & 0 \\
\hline 3. Good & $7.6-8.5$ & 0 & 0 & 6 & 20 & 14 & 46.66 \\
\hline 4. Fairly Good & $6.6-7.5$ & 0 & 0 & 0 & 0 & 0 & 0 \\
\hline 5. Fair & $5.6-6.5$ & 13 & 43.33 & 20 & 66.66 & 14 & 46.66 \\
\hline 6. Poor & $3.6-5.5$ & 17 & 56.66 & 4 & 13.33 & 0 & 0 \\
\hline Very Poor & $0-3.5$ & 0 & 0 & 0 & 0 & 0 & 0 \\
\hline Total & & 30 & 100 & 30 & 100 & 30 & 100 \\
\hline
\end{tabular}

\section{b. Detail}

The application of Explicit Teaching Strategy in improvement of the students' reading comprehension in terms of detail can be seen the difference by considering the result of the students' Diagnostic Test and the students' achievement after taking action in Cycle I and Cycle II through the application of Explicit Teaching Strategy in teaching and learning process. 
Table 3: The Percentage of the Students' Detail Achievement

\begin{tabular}{|c|c|c|c|c|c|c|c|}
\hline \multirow{3}{*}{$\begin{array}{l}\text { No Classification } \\
\text { Range }\end{array}$} & & \multirow{2}{*}{\multicolumn{2}{|c|}{$\begin{array}{c}\text { Non ET } \\
\text { D-Test }\end{array}$}} & \multicolumn{4}{|c|}{ The Application of ET } \\
\hline & & & & \multicolumn{2}{|c|}{ Cycle I } & \multicolumn{2}{|c|}{ Cycle II } \\
\hline & & Freq & $\%$ & Freq & $\%$ & Freq & $\%$ \\
\hline 1. Excellent & $9.6-10$ & 0 & 0 & 0 & 0 & 1 & 3.33 \\
\hline 2. Very Good & $8.6-9.5$ & 0 & 0 & 0 & 0 & 0 & 0 \\
\hline 3. Good & $7.6-8.5$ & 0 & 0 & 4 & 13.33 & 18 & 60 \\
\hline 4. Fairly Good & $6.6-7.5$ & 0 & 0 & 0 & 0 & 0 & 0 \\
\hline 5. Fair & $5.6-6.5$ & 15 & 50 & 23 & 76.66 & 11 & 36.66 \\
\hline 6. Poor & $3.6-5.5$ & 15 & 50 & 3 & 10 & 0 & 0 \\
\hline 7. Very Poor & $0-3.5$ & 0 & 0 & 0 & 0 & 0 & 0 \\
\hline Total & & 30 & 100 & 30 & 100 & 30 & 100 \\
\hline
\end{tabular}

The data above shows the percentage of the students' detail achievement in Diagnostic Test indicates that 15 students (50\%) get fair and also 15 students $(50 \%)$ get poor and none of the students for the other classification. After taking Cycle I by using Explicit Teaching Strategy, the percentage of the students' detail achievement improves where 4 students (13.33\%) get good, 23 students (76.66\%) get fair and 3 students (10\%) get poor and none of the students for the other classification.

\section{The Result of the Students' Activeness in Teaching and Learning Process}

The result of observation of the students' activeness in teaching and learning process toward the application of Explicit Teaching Strategy to improve 
the students' reading comprehension at the second grade of SMP Negeri 33 Makassar, which was conducted in 2 cycles during 8 meetings, was taken by the observer through observation sheet. It can be seen clearly through the following table:

Table 4: The Observation Result of the Students' Activeness in Learning Process

\begin{tabular}{|c|c|c|c|c|c|c|}
\hline \multirow{2}{*}{ Cycle } & \multicolumn{4}{|c|}{ Meetings } & \multirow{2}{*}{$\begin{array}{l}\text { Average } \\
\text { Score }\end{array}$} & \multirow{2}{*}{$\begin{array}{c}\text { Improvement } \\
(\%)\end{array}$} \\
\hline & I & II & III & IV & & \\
\hline I. & 55.8 & 62.5 & 65.8 & 69.2 & $63.33 \%$ & \multirow{2}{*}{$8.97 \%$} \\
\hline II. & 64.2 & 72.5 & 75 & 77.5 & $72.3 \%$ & \\
\hline
\end{tabular}

The result above is formulated based on the technique of data analysis and the students' score that are collected through observation sheet. The table above shows that in Cycle I the students' activeness in each meeting improvement significantly. It can be see clearly in table that the students' activeness in the fourth meeting is higher than the first, the second and the third meeting, where the first meeting in Cycle I the students' activeness (55.8\%) and it improves $(62.5 \%)$ in the second meeting, and then students' activeness in the third meeting. In the Cycle II the improvement of the students' activeness is up and down. Where in the first meeting in Cycle II the students' activeness is $(64.2 \%)$ improves to $(72.5 \%)$ in the second meeting and it is higher than the first meeting. In the third meeting of Cycle II, the students' activeness becomes (75\%). Than in the forth meeting the students' activeness increases to $(77.5 \%)$. This is caused by the teaching material is really interesting for the students' and the teacher gives them game when opens the class. So the average of the students' activeness in Cycle II is (72.3\%). Later, the result is presented in the graphic below that shows the average of students' activeness in the Cycle I and Cycle II. 


\section{CONCLUSIONS}

Based on the finding and discussion of the previous chapter, the researcher had concluded the research as follows:

1. The use of Explicit Teaching Strategy was able to improve the students' reading comprehension at the second grade of SMP Negeri 33 Makassar. The mean score of Diagnostic Test, Cycle I, and Cycle II was ( $4.94>6.11>7.26)$, in percentage D-Test to C I was $24.1 \%$ and C I to C II was $18.8 \%$.

2. The use of Explicit Teaching Strategy was able to improve the students' main idea at the second grade student of SMP Negeri 33 Makassar. The mean score of Diagnostic Test, Cycle I, and Cycle II was (4.86 > 6.13 > 7.2), in percentage D-Test to C I was $26.13 \%$ and C I to C II was $17.45 \%$.

3. The use of Explicit Teaching Strategy was able to improve the students' detail at the second grade student of SMP Negeri 33 Makassar. The mean score of Diagnostic Test, Cycle I and Cycle II was $(5>6.1>7.33)$ in percentage D-

Test to C I was $22 \%$ and C I to C II was $20.16 \%$.

\section{REFERENCES}

Akmal, Muhammad (2003). Increasing the Reading Comprehension Achievement of the Second year students of MTA ANNURAIN WATAMPONE by Using Three Phase of Reading Techniques UIN Alauddin Makassar.

Anita, A. Charles, Hugest. (2011). Effective/Efficient Teaching. New York: The Guild ford.

Basri, Nurbaya. 2010. Developing Students' Reading Comprehension through Cooperative Integrated Reading method. Thesis FKIP Unismuh Makassar. 
Brown, Douglas, H. 2001. Teaching by Principles and Interactive Approach to Language Pedagogy. Second Edition. Longman: San Pransisco

Budiyanto. 2004. Petunjuk Pelaksanaan Proses Belajar Mengajar dan petunjuk pelaksanaan Sistem Penilaian. Jakarta: Depdikbud.

Byrnes. (1988). Teaching Reading. London: Scott, Foresman and Company. Chastain, K. 1988. Developing Second Language Skills: Theory and Practice. The $3^{\text {rd }}$ ed. Orlando, Harcourt Brace Jovanovich.

Depdikbud. (1985). Petunjuk Pelaksanaan Proses Belajar Mengajar dan Petunjuk Pelaksanaan System Penilaian. Jakarta: Depdikbud.

Depdikbud. (1985). Garis-garis Besar Pengajaran Bahasa Inggris. Jakarta: Depdikbud.

Gay, L. R. 1981. Education Research. Ohio: Bell and Howel Company. Goeke. (2008). Strategies for Meaningful Direct Teaching. Merrill, Pearson.

Hall Tracey. 2011. The Application of Explicit Instruction Strategy. Retrieved from:http://www.aasa.org/issueandinsight/ $\underline{\text { districtOrganization/ReForm/index.htm }}$ Accessed on September $25^{\text {th }}$ 2011.

Harmer, Jeremy. (1991). The Practice of English Language Teaching. New York: Group UK United.

Harrist. 1980. Reading Strategies and Practices: Third Edition. Jakarta: Kencana. Kustaryo. (1988). Reading Technique in Second. New York: The Ronald Press Company.

Lepzig, Diane H. 2001. Reading Rockets, (Online), Retrieved from:http://www.readingrockets.org/article/352 Accessed on M a y $30^{\text {th }} 2010$

Nuttal, Christine. (1987). Teaching Reading Techniques in a Foreign Language.London: Heineman Education Books. Organization and Practice. Massachusetts: Newbury House Publisher, Inc.

Nuttal, N. (1988). Teaching Reading Skill in Foreign Language. Oxford: Heinemann International Publishing Company. 
Ph, D, Tracey Hall. (2002). Explicit Instruction. U.S Office of Special Education Programs.

Yatim, Nurdin. (1996). Scientific Reading Paper. Unpublished Thesis: Makassar: Hasanuddin University (UNHAS) 